Informasi - ISSN (p) 0126-0650; ISSN (e) 2502-3837

Vol. 5o, No. 1 (2020), pp. 71-84, doi: http://doi.org/10.21831/informasi.v50i1. 29106

\title{
A comparative study of BRTV and NTA Maiduguri regarding their compliance with Nigeria broadcasting code on religious programming
}

\author{
Ibrahim Uba Yusuf \\ Department of Mass Communication, Faculty of Social Sciences, \\ University of Maiduguri, Nigeria \\ Ibrahim.mcm@unimaid.edu.ng \\ Musa Usman \\ Department of Mass Communication, Faculty of Social Sciences, \\ University of Maiduguri, Nigeria \\ alhmusa20o@gmail.com \\ Adamkolo Mohammed Ibrahim \\ Department of Mass Communication, Faculty of Social Sciences, \\ University of Maiduguri, Nigeria \\ adamkolo@unimaid.edu.ng
}

Article History: Received 2019-12-27, Revised 2020-07-22, Published 2020-07-30

\begin{abstract}
The regulation of broadcast religious programming is a critical challenge the National Broadcasting Commission (NBC) is facing in Nigeria. In Maiduguri, the capital of the north-eastern Nigerian state of Borno where religion forms a core part of the people's culture, a great deal of Borno Radio Television (BRTV) and Nigerian Television Authority Maiduguri's (NTA Maiduguri) airtime is allocated to Islamic preaching during the Muslim's annual Ramadan fasting. However, there is a dearth of research on whether the airtime those broadcast stations allocate to Islamic programming complies with the NBC code on religious programming. This research gap formed the main research question of this study which was conducted during the second quarter of 2019. Primary data were collected using key informant interviews with five personnel from the two broadcast stations and the Maiduguri office of NBC, while secondary data were obtained through the review of official documents. Key findings showed that the airtime allocated to religious programmes exceeded the $10 \%$ NBC limit, BRTV allocated more airtime to religious programmes than NTA Maiduguri and Islamic programmes were allocated more airtime than programmes of other religions. Recommendations on how to improve compliance to NBC's regulations were offered at the end.
\end{abstract}

Peraturan program siaran keagamaan merupakan tantangan bagi National Broadcasting Commission (NBC)/Komisi Penyiaran Nasional di Nigeria. Maiduguri, 
ibukota Negara bagian Borno, Nigeria Timur Laut di mana agama merupakan bagian inti dari budaya masyarakat, banyak Radio Televisi Borno (BRTV) dan Otoritas Televisi Nigeria Maiduguri (NTA Maiduguri) mengalokasikan jam tayang untuk khotbah Islam selama Ramadhan. Namun, ada kelangkaan penelitian tentang apakah jam tayang yang disiarkan oleh stasiun-stasiun siaran itu untuk program Islami. Kesenjangan penelitian ini membentuk pertanyaan penelitian utama yang dilakukan selama kuartal kedua 2019. Data penelitian ini dikumpulkan menggunakan wawancara informan kunci dengan lima personel dari keduanya stasiun siaran dan kantor Maiduguri NBC, sementara data sekunder diperoleh melalui telaah dokumen resmi. Temuan penelitian ini menunjukkan bahwa "airtime" (jam tayang) dialokasikan untuk program keagamaan yang melebihi batas 10\% NBC, BRTV mengalokasikan lebih banyak "airtime" ke program keagamaan dari NTA Maiduguri dan program Islam dialokasikan lebih banyak "airtime" daripada program agama lain. Implikasi dari penelitian ini adalah perlunya kepatuhan terhadap peraturan $N B C$.

Keywords: BRTV, Television and Nigerian Broadcast Industry, NTA, Religious Programming, NBC and Nigeria Broadcasting Code.

\section{INTRODUCTION}

Since when Nigeria was granted political independence in 1960, the guarantee for the freedoms of "religious association, expression and practice" has been provided for in all the Constitutions drafted and promulgated (Adum, Ojiakor \& Nnatu, 2019). However, optimistic as this may be, there is one important thing that the Constitutions "have not granted citizens, in a straightforward, uncomplicated manner", and that is the "freedom to own and operate a broadcast medium" (Ukah, 2011, p.39). Nigeria is a multireligious and multicultural society; in a society such as this, "the role of the state concerning religious communication is critical" as Hackett argues,

the role of public religion in a nationstate in political transition [as Nigeria obviously is] ... provides an important insight into the mechanics of religious representation in the mediated public sphere. (2006, p.167)

Despite being an important factor of national identity and cohesion, religion has also been a critical factor of disunity and intolerance among Nigerians. There exists a thorny and protracted history of "mutual suspicion” among various Nigeria's religious and ethnic groups, a factor that is constantly regarded as one of the main reasons that the Nigerian Government has always treaded "a cautious approach to the liberalisation of the media as well as the role of the state in the strategies of public representation of religion" (Johannes, 2008; Falola \& Heaton, 2008, p.238f).

The volatile nature of the Nigerian religious ambience has been indicated as having necessitated "the institutionalisation of a policy of prior restraint on evangelising communities in relation to religious broadcasting" (Bala, 2000, p.107; Ukah, 2011, p.40). Also, the abuse of religion and the use of mass media to stir conflicts have led the government to adopt new policies (see Appendix) about religious broadcasting (Bala 2000).

These are serious factors that cannot be ignored when discussing religious broadcasting in Nigeria. Hence, this paper notes that despite the role played by these factors in influencing the state policy on religious broadcasting, the Government's roles as a monopoliser in the pre-deregulation era and currently, "as a principal player in the media market" are responsible for the ambiguities manifested "in the state policies and politics of deregulation" of the broadcast media industry especially in light of religious broadcasting (see Ukah, 2011, p.40).

The utilisation of conventional broadcast media by religious scholars especially during the Muslim Ramadan fasting period has made them emerged as stakeholders at the 
forefront of patronising the media. The media have enormous derivable benefits - making huge turnovers to sustain the operation. The priority intention of every scholar utilising the broadcast media as a channel of communication is to garner more followership to his sect; or create an identity or authority towards understanding what religion entails and how it should be practised.

Taking into cognizance that clients with airtime purchasing power have access to the media, which serve as the only yardstick that guarantees which scholar features on, for example, a television or a radio show and when poses a serious threat to the quality of the broadcast content. Although there is the doctrine of 'fairness', which seeks to provide the 'right of reply' to other parties, say, aggrieved groups or individuals to counternarrate allegations or criticisms, not all broadcast media seem to be comfortable with this journalism principle and code of ethics. Available records have shown that many television and radio stations have violated one NBC code or another, particularly codes regarding broadcasting religion and have, consequently, been served with warning letters and even sanctioned.

Considering the powers of broadcast media"toformand influencethought,conduct and actions, it is appropriate and legitimate to prohibit licenced broadcast stations from fomenting and disseminating hate speech and national disunity" (Adum et al., 2019; Ibrahim, Pate \& Usman, in press; Ukah, 2011; p.44). However, as powerful as NBC is, considering the powers conferred to it by law, how has it been able to achieve compliance of the broadcast code in the Nigerian broadcast industry? This study was guided by several research questions which, if answered, could provide a further understanding of NBC's and religious broadcasting in Nigeria. The questions are as follows: Has NBC been able to regulate television broadcasting considering religious programmes and licensing? Are television stations adhering to the NBC code on religious broadcasting? How frequently do BRTV and NTA Maiduguri broadcast religious programmes? What are the similarities in the mode of the broadcast of religious programmes between BRTV and NTA Maiduguri? Have there been any ethical violations in the broadcast of religious programmes by BRTV and NTA Maiduguri?

\section{LITERATURE REVIEW}

\section{The concept of regulation}

Characteristically, the broadcast media are powerful especially in the manner they shape public opinion, reaching millions of audiences in voice and image (Dominick, 2009; Okunna, 2005). The evolution and development of Nigerian broadcast industry are historical; and for 6o years, from 1932 to 1992, the state had monopolised the industry, using the broadcast mediaas toolsforpolitical, economic, social and cultural manipulation of the masses. The literature has consistently demonstrated that as much as the broadcast media possesses the potential to stimulate socio-economic development as witnessed in social agricultural developments in SouthEast Asia (Anifowose, 2013; Ibrahim, 2017), the broadcast media also have the potential to be used as 'electronic weapons' to incite violence and cause war as seen in the chronic ethnoreligious conflicts in various parts of Nigeria (Adebiyi \& Salaudeen, 2016; Adum et al., 2019). Because of these and many other reasons, various governments deemed it necessary to keep its monopoly of controlling the broadcast industry. To understand what regulation is, Harvey defines the concept regulation which:

Involves intervention by the state in areas of economic, social or cultural life according to whatever political norms are characteristic of that nation state. Regulations maybeissued by presidential decree, by religious prescription or by legislative action within a system of representative democracy. (1999, p.2)

Regulations can be governed directly by government, as it was in Nigeria before 1992 or through statutory outfits invested with some degree of autonomous powers by the government such as National Broadcasting Commission (NBC) and the National 
Communications Commission (NCC). In the realm of broadcasting, regulation involves the authoritative issuance of permission or the granting of a licence to broadcasting organisations. The cultural norms of the society influence broadcasting regulation which, in turn, "contributes to the shaping of these norms and can at times have a significant impact on the form and content of programmes" (Harvey; 1999, p.3; Ihechu \& Okugo, 2013), thus, affecting the economic and management structures or the political economy of broadcasting.

\section{Broadcast regulations in Nigeria: The need to maintain standards}

The constitutional provisions for the regulation and deregulation of the electronic media were boosted further by the promulgation of the National Broadcasting Commission (NBC) Decree No. 38 of 1992, which was described as a major policy shift of the government. The Decree was signed into law on 20 August 1992 by the President Ibrahim Badamasi Babangida Military Administration and amended by Decree No. 55 of 1999, which was promulgated by then military Head of State, General Abdulsalami Abubakar on 26 May 1999, just three days before he vacated office (Ukah, 2011).

Decree No. 38 that established NBC, outlined its responsibilities the key of which include the following: (i) receiving, processing and considering applications for theownership of broadcast stations (radio, television, cable, direct satellite, etc.); (ii) regulating and controlling the broadcast industry; (iii) maintaining the principle of equity and fairness in the broadcasting industry; (iv) receiving, considering and investigating complaints from members of the public (private and corporate) regarding broadcast contents and the conduct of broadcasting stations; (v) setting standards about the contents and materials for broadcast; and (vi) establishing a national broadcasting code. Furthermore, the NBC is to intervene and arbitrate in conflicts in the broadcast industry, ensure qualitative manpower development, monitor broadcasting for harmful emission, interference and illegal broadcast and set and apply sanctions, including revocation of licences of defaulting stations (Malaolu, 2012; Tijani-Adenle, 2019). As spelt out in the law establishing the electronic media regulatory agency, NBC shall:

ensure that a licensed station shall be used to promote national interest, unity and cohesion and that it shall not be used to offend the religious sensibilities or promote ethnicity, sectionalism, hatred and disaffection among the peoples of Nigeria (NBC Decree 38, Section 9(1e)) .... The law setting up the NBC, and its amendment, deployed the concepts of "national interest", "public interest" and "interest of the public" six times (NBC Decree No. 38 Section 2(n); 4.4; 9(1e); 25(8d); NBC (Amendment Decree No. 55 Section $10(2 \mathrm{~B}) ; 10(8 \mathrm{~A})$. Nowhere in the text were these concepts defined or given content as legitimate objectives to be safeguarded, protected, or promoted by private broadcasters. Particularly in Nigeria, what amounts to "national interest" often represents the interest of the politician(s) or a certain segment of the political class or elite who evoke the notion rather than the "common good", the good of the largest segment of the citizenry. Ordinarily, national interest may be conceptualised as any action, circumstances, policies, or decisions that are generally considered to benefit the nation-state as a whole. However, in Nigeria, as historical experience amply shows, the "state" is not often synonymous with the public or the citizens of the nation such that the interest of the abstraction called the "state" becomes coterminus with what benefits the general public. (Ukah, 2011, p.44)

The so-called national/public interest stipulated in the NBC law also re-appeared in Section 10a, which prohibits the NBC from granting a broadcast licence to a religious organisation. However, as mythical as the concept of 'national/public interest' may seem in this law, the law keeps mute over the reasons or justifications for the blanket ban (Adum et al., 2019; Ukah, 2011). This paper argues that this ban is uncalled for in as much as there is an 
explicit constitutional provision guaranteeing freedom of expression as well as the provision in the NBC law that explicitly requires applicants for a broadcast licence to "give an undertaking that the licenced station shall not be used to offend the religious sensibilities or promote ethnicity, sectionalism, hatred and disaffection among the peoples of Nigeria" (Ukah, 2011, p.44). Cited in Ukah (2001), Bala (2000, p.107) suggests that:

The decision not to license these [religious] stations may be due to the volatile religious atmosphere in the country, the abuse of religious speech in the past, the excessive politicization of religion, and the constant use of the mass media to heighten tensions. (p.45)

Some of the important aims of the deregulation of the broadcast industry are the democratisation of access and participation (Ibrahim et al., 2019) as well as plurality and diversity. However, this paper agrees with Ukah's (2011) argument that "the prohibition of ownership of broadcast media by religious organisations starkly sabotages this objective" (p.45).

\section{Major approaches of NBC broadcast regulations in Nigeria}

\section{a. Regulation through licencing}

A primary function of NBC has to do with the licensing of broadcast organisations. NBC is required by law to make the requirements and procedure for the acquisition of licence public. For instance, NBC (2009) states that "A prospective applicant must have a limited liability company registered with the Corporate Affairs Commission in which Nigerians hold majority shares. Its Memorandum of Association and Article of Association must include broadcasting" (p.1). Because NBC is not independent, its recommendations can be set aside, by the Minister and, or, the President. Section 9 (3) of Decree No. 38 created uncertainty in the process of securing a licence when it states that, "Compliance with the requirements specified in subsection (1) of this section shall not entitle an applicant for the grant of licence" (Nwanze, 2003, p.250). The provision gives latitude for the licensing laws to be manipulated and for the licensing to be motivated by political considerations (Ihechu \& Okugo, 2013; Ukah, 2011).

Furthermore, an area of big concern is licence fees. The fees are expensive that they seemed to be fixed to make it extremely difficult for private broadcasters to obtain the licence, which could affect public access and participation negatively (Ibrahim et al., 2019). Also, a licence duration of only fiveyear cannot be said to be long enough for the organisations to recoup their investment (Ukah, 2011). This situation can force private broadcast media outfits to over depending on commercialisation which, as Okunna (2005, p.89) citing Popoola (2004) describes the broadcast media as "shying away from their primary responsibilities of educating, informing and enlightening the citizenry... and violates the fundamental rights of people...to receive the right type of information".

\section{b. Regulation through monitoring}

The NBC code stipulates that "Every licence is required to adhere to a minimum of $60 \%$ local broadcast content for open television and $80 \%$ local broadcast content for radio. The cable/satellite retransmission stations are mandated to reflect a minimum of $20 \%$ " (NBC, 2009, p.3). The code further requires that programmes and advertisement for family belt shall be devoid of sex or overt sexual behaviour, nudity, violence, bloodletting, smoking, alcohol, drug abuse, denigration of womanhood, offensive, lewd or vulgar language, expression and presentation, etc. and that family broadcast to be between the hours of $07 \mathrm{pm}$ and $10 \mathrm{pm}$ daily (a period when the family as a unit is presumed to be together to watch television). The code also prohibits the provision of licence for religion broadcasting (Ihechu \& Okugo, 2013; Ukah, 2011). The code, however, permits broadcasting of religious programmes with a stipulation that "religious broadcasts shall not exceed 10\% of the total weekly airtime of any broadcaster" (NBC, 2016, p.47). These aspects are being monitored daily by the staff of the monitoring department of the NBC, spread across all 
state and zonal offices. Figure 1 shows an illustration of how broadcast stations comply with or deviate from compliance with the NBC code on religious programming.

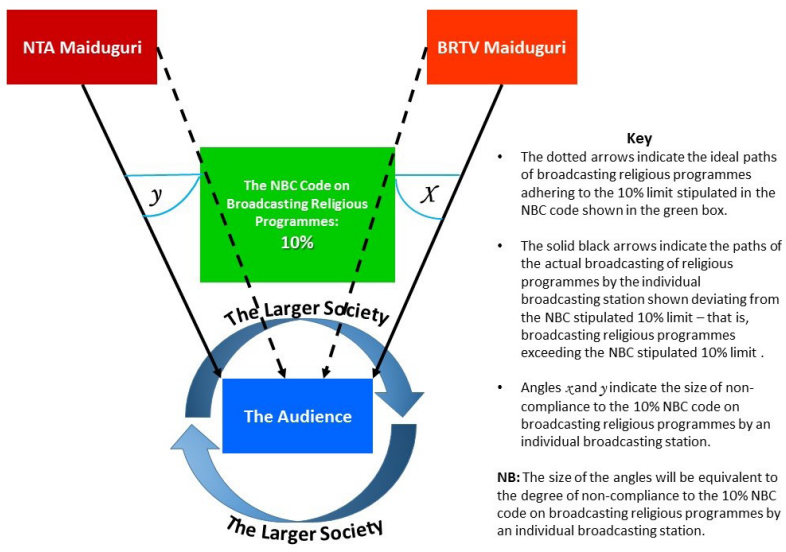

Figure 1: A diagrammatic representation of how broadcast stations comply with or refuse to comply with the NBC code on religious programming. Source: Authors

Both BRTV and NTA Maiduguri target their programmes to the members of the audience in society. Being regulated by NBC, their religious content is not, statutorily, supposed to exceed $10 \%$ of their total weekly broadcasts. The two dotted arrows emanating from the two broadcast stations represent the ideal broadcast paths complying with the NBC code, as can be seen, passing through the green box at the centre (which represents the NBC code zone) towards the audience in the larger society. The larger society, which is represented by two arrows indicating a continuous circular motion refers to communities, villages, towns and cities which the broadcasting stations target their religious programmes at. Besides, the two solid arrows emanating from the two broadcasting stations represent the actual broadcast paths deviating away from the NBC code, as can be seen, by-passing the green box at the centre (representing the NBC code on broadcasting religious programmes zone) targeting the audience in the larger society. On both the right and left sides, between each of the two solid arrows and the green box at the centre are two unknown angles represented by ' $x$ ' and ' $y$ ' respectively. The size of the angles will determine the degree to which each station deviates away, or refuses to comply with the NBC code. It is recommended that future research should adopt a quantitative approach to determine the stations' actual non-compliance with the NBC code numerically.

\section{Regulation through Sanctioning}

NBC uses four major types of sanctions to punish erring licenced broadcasters who violated either Decree 38 or the National Broadcasting Code. These include (i) licence revocation, (ii) the shutting down or sealing up of a station or transmitter and (iii) the seizure or forfeiture of equipment and suspension of licence (Ihechu \& Okugo, 2013, p.16; Ukah, 2011). Another type of sanctioning erring licenced broadcast stations involves a written warning, which is aimed at making the affected station to stop a further violation of the code and deterring future breach of the code. Sanctioning is imposed with a given timeframe the expiration without compliance of which attracts a fine to be imposed. The last type of sanctioning involves fines and stiffer sanctions for not complying with earlier sanctions. However, the offences which can attract these types of sanctions can are not clear. However, the code is silent on what and what constitutes a "serious breach". This scenario suggests the notion that NBC may be biased toward certain interests, which dictate "whether a station should be sanctioned or not", a circumstance that arises when NBC acts arbitrarily or goes against its own rules (Ihechu \& Okugo, 2013, p.17).

\section{Theoretical Framework}

Thestudy is anchored on the Gatekeeping Theory. The Media Gatekeeping Theory focuses on media regulation of information flow. The term gatekeeping was coined by an Austrian psychologist Kurt Lewin in 1947.

In the study of mass communication, the term refers to the process of filtering or blocking unwanted information or messages. The gatekeepers refer to persons who (a) controls access to information; (b) influence decision making and actions; c) having influence. Lewin illustrated the role of the gatekeeper with the role of a mother who determines what is good for her children. 
In this case, the gatekeeper is the owner of the publishing firm who influences decision making and action as well as influencing to manipulate information in the firm to conform to his/her interest. The gatekeeper (owners) has to decide what to publish and what not to publish in a publication. Today, Mass Media play a gatekeeping role as they decide what the people should watch, listen and enjoy. The gatekeeping processes are dictated by the owners of the firm. The theory posits that gatekeeping determines not only which information is selected, but also what the content and nature of messages, such as news, will be. The theory describes the powerful process through which events are covered by the mass media, explaining how and why certain information either passes through gates or is closed off from media attention. The rationale for using this theory is hinged on the selection process. Religious programmes are broadcast based on the proprietor's discretion, perhaps the audience and the ability of the sponsors to buy airtime in the broadcast station.

\section{METHODS}

\section{Research design}

A qualitative survey approach was adopted, specifically, the key informant interview approach (Creswell \& Poth, 2017) and archival review or analysis (McBurney \& White, 2010). As Fontana and Prokos (2007) noted, "Interviewing is one of the most common and powerful ways in which we try to understand our fellow humans" (p.9). The interview approach was chosen because of two key reasons: (i) social science researchers often prefer interview methods to "understand the experiences of their subjects" (ii) interview provided the researcher with the opportunity to understand, first-hand and in their own words, the participants' experiences (Tijani-Adenle, 2019, pp.76-77).

Archival review or analysis involves "answering empirical questions" (Goodwin, 2009, p.372) by using "factual information in existing records" (McBurney \& White, 2010, p.228) that have "already been gathered for some reason aside from the research project at hand" (Goodwin, 2009, p.386).

\section{Participants and sampling}

Using a purposive sampling technique, 5 participants were selected. Selection of the participants was made based on the following criteria: (i) working with the NBC (ii) working in the programmes departments of the two broadcast stations; (iii) was conversant with the NBC regulations codes and/or monitoring broadcast stations' compliance to the code or otherwise; and (iv) was conversant with the programmes production and presentation (i.e., conversant with the programmes schedules) of the broadcast organisations. The participants were management personnel of the Maiduguri office of the NBC, four (two management and two programmes department) personnel each of BRTV and NTA Maiduguri respectively. To ensure anonymity and to facilitate smoother data analysis, each participant was assigned a serial number (see Lindlof \& Taylor, 2002). Key informant interview methodology was chosen because key informants reveal information from organisational insiders, or stakeholders, i.e., management staff members responsible for policymaking and crafting messages and key stakeholders (Lindlof \& Taylor, 2002). The data were analysed using a thematic approach (Van Dijk, 1993). Cited in Tijani-Adenle (2019, p.88), thematic analysis is:

An independent approach within the qualitative descriptive methodologies" (Vaismoradi, Turunen \& Bondas, 2013, p.404) that involves identifying similarities and relationships in qualitative data known as "themes and patterns" (Aronson, 1995, p.1) and analysing and explaining their meanings to reflect the "complex relationships across participants' experiences" (Henderson \& Baffour, 2015, p.1965).

\section{RESULTS AND DISCUSSION}

Fourdifferentprogrammeschedulesfrom NTA Maiduguri and BRTV were obtained. Additionally, Heads of programmes in the two organizations were interviewed, while the Zonal Coordinator of NBC Maiduguri 
Office was interviewed.

RQ2 sought to know the religious programmes and their broadcast time (airtime) on both BRTV and NTA Maiduguri. To answer this RQ, the programme schedules of BRTV and NTA Maiduguri for the Ramadan 2019 period and beyond, that is, the second quarter of 2019 (Q2) was obtained and analysed. Tables 1 to 4 show the extracted schedules for religious programmes broadcast on BRTV Maiduguri.

Table 1 shows the programme schedule for the month of Ramadan. Religious programmes occupied the entire schedule.
The programmes were $100 \%$ Islamic, even though there were a few pockets of about 30 minutes of news broadcasts periodically. Worthy of note is that there was a break in the transmission that lasts several hours between the morning and afternoon transmission shifts. In the previous Ramadan season, as noted by Imam (personal communication, 2019), the break was cancelled because of heavy traffic of sponsored Islamic religious programmes. Sponsors of most of the Islamic programmes during the annual one-month Ramadan period have permanently booked prime times for the religious programmes broadcast.

Table 1: The inventory of religious programmes contained in the programme schedule of BRTV Maiduguri

\begin{tabular}{|c|c|c|c|c|c|}
\hline Title of Programme & Presenter & $\begin{array}{c}\text { Time of } \\
\text { Broadcast }\end{array}$ & Duration & Sponsor & Genre \\
\hline $\begin{array}{l}\text { Tafseer from Government } \\
\text { House Maiduguri }\end{array}$ & $\begin{array}{l}\text { Sheikh Ibrahim } \\
\text { Mustapha Al-Malik }\end{array}$ & 7:00 am & One hour & Free & Recorded \\
\hline $\begin{array}{l}\text { Tafseer from Imam Bukhari } \\
\text { Mosque }\end{array}$ & $\begin{array}{l}\text { Sheikh Modu } \\
\text { Mustapha }\end{array}$ & $8: 00 \mathrm{am}$ & One hour & Unknown & Recorded \\
\hline Tafseer from Hausari & Sheikh Kabiru Danyaya & 9:00 am & One hour & Unknown & Recorded \\
\hline $\begin{array}{l}\text { Tafseer from Umar Ibn } \\
\text { Khattab Mosque Bulumkutu }\end{array}$ & Sheikh Babunu Bukar & $10: 00 \mathrm{am}$ & One hour & $\begin{array}{l}\text { Umar Ibn Khattab } \\
\text { Mosque }\end{array}$ & Recorded \\
\hline $\begin{array}{l}\text { Tafseer from Taha Qur'anic } \\
\text { Memorisation Centre }\end{array}$ & $\begin{array}{l}\text { Imam Goni } \\
\text { Muhammad Ali } \\
\text { Gapchiya }\end{array}$ & $11: 00 \mathrm{am}$ & One hour & $\begin{array}{l}\text { Taha Qur'anic } \\
\text { Memorisation Centre }\end{array}$ & Recorded \\
\hline $\begin{array}{l}\text { Tafseer from Shettima Ali } \\
\text { Monguno Mosque Mafoni }\end{array}$ & $\begin{array}{l}\text { Goni Modu Goni } \\
\text { Zarami }\end{array}$ & $12: 00 \mathrm{pm}$ & One hour & Unknown & Recorded \\
\hline $\begin{array}{l}\text { Tafseer from Central } \\
\text { Mosque }\end{array}$ & Goni Abba Umar & 01:00 pm & One hour & Free & Recorded \\
\hline $\begin{array}{l}\text { Tafseer from Al-Umma } \\
\text { Mosque Board of Internal } \\
\text { Revenue }\end{array}$ & $\begin{array}{l}\text { Dr Muhammad } \\
\text { Abubakar Talha }\end{array}$ & 04:00 pm & One hour & $\begin{array}{l}\text { Board of Internal } \\
\text { Revenue }\end{array}$ & Recorded \\
\hline $\begin{array}{l}\text { Tafseer from } 1000 \text { Ahmad } \\
\text { Jaha Foundation }\end{array}$ & Late & 05:00 pm & One hour & Ahm & Recorded \\
\hline $\begin{array}{l}\text { Bayan Kla Asham Mben } \\
\text { (Kanuri) }\end{array}$ & Any prominent scholar & $06: 25 \mathrm{pm}$ & $\begin{array}{c}5 \\
\text { minutes }\end{array}$ & Free & Recorded \\
\hline Jawabi Kan Azumi (Hausa) & Any prominent scholar & $06: 25 \mathrm{pm}$ & $\begin{array}{l}5 \\
\text { minutes }\end{array}$ & Free & Recorded \\
\hline $\begin{array}{l}\text { Tafseer from Al-Amin } \\
\text { Daggash Mosque (Hausa) }\end{array}$ & $\begin{array}{l}\text { Sheikh Muhammad } \\
\text { Mustapha }\end{array}$ & 08:00 pm & One hour & $\begin{array}{l}\text { Al-Amin Daggash } \\
\text { Islamic Foundation }\end{array}$ & Recorded \\
\hline $\begin{array}{l}\text { Tafseer from Ibrahim Saleh } \\
\text { Mosque Gwange (Hausa) }\end{array}$ & Sheikh Ibrahim Saleh & 09:00 pm & One hour & $\begin{array}{l}\text { Sheikh Ibrahim Saleh } \\
\text { Islamic Foundation }\end{array}$ & Recorded \\
\hline $\begin{array}{l}\text { Tafseer from Indimi } \\
\text { Mosque (Hausa) }\end{array}$ & $\begin{array}{l}\text { Dr Muhammad Alhaji } \\
\text { Abubakar }\end{array}$ & $10: 00 \mathrm{pm}$ & One hour & Indimi Islamic Trust & Recorded \\
\hline $\begin{array}{l}\text { Tafseer from Imam Malik } \\
\text { Islamic Centre (Kanuri) }\end{array}$ & Sheikh Abubakar Kyari & $11:: 00$ pm & One hour & $\begin{array}{c}\text { Imam Malik Islamic } \\
\text { Centre }\end{array}$ & Recorded \\
\hline $\begin{array}{l}\text { Tafseer from MOGCOLIS } \\
\text { Mosque }\end{array}$ & Sheikh Tijjani Umara & $12: 00 \mathrm{pm}$ & One hour & MOGCOLIS & Recorded \\
\hline
\end{tabular}


Ibrahim Uba Yusuf, Musa Usman, \& Adamkolo Mohammed Ibrahim, A comparative study of BRTV and NTA...

Table 2 contains a breakdown of religious programmes broadcast in BRTV Maiduguri during the $2^{\text {nd }}$ Quarter of 2019. A quarter, which is a period of three months supersedes the one-month Ramadan fasting period. In a state with a large population of Christian citizens, surprisingly, even during non-Ramadan periods there is virtually no allocation of airtime for Christian religious programming. Concisely, the data show that during the three months ( $2^{\text {nd }}$ quarter), from Sunday to Saturday every week, there was at least two to three hours of Islamic preaching programme on air in BRTV each day; and, nearly $50 \%$ of the programmes were sponsored - pulling in some ready cash to the station. However, it is not known whether the revenue generated from Islamic and other religious programmes broadcast (if any) during that quarter corresponding to the vast amount of airtime expended. Also, it is not known whether the revenues generated got into the station's coffers. Future research should examine these issues.

Table 2: The inventory of religious programmes contained in the programme schedule of BRTV Maiduguri during the $2^{\text {nd }}$ Quarter of 2019

\begin{tabular}{|c|c|c|c|c|c|}
\hline Title of The Programme & Presenter & $\begin{array}{l}\text { Days of } \\
\text { Broadcast }\end{array}$ & Time & Duration & Sponsor \\
\hline MCAN Da'awah & $\begin{array}{l}\text { Alternating members } \\
\text { of Muslim Corpers } \\
\text { Association of Nigeria }\end{array}$ & Sunday & 09:00 am & 30 minutes & Free \\
\hline $\begin{array}{l}\text { Babban Guzuri (Hausa) } \\
\text { Repeat broadcast }\end{array}$ & $\begin{array}{c}\text { Sheikh Muhammad } \\
\text { Mustapha }\end{array}$ & Sunday & $\begin{array}{c}\text { 01:00 } \\
\mathrm{pm}\end{array}$ & One hour & $\begin{array}{c}\text { Ahmed Babawo } \\
\text { Jaha }\end{array}$ \\
\hline Riyadus Saliheen & Sheikh Abubakar Kyari & Sunday & 09:00 pm & One hour & $\begin{array}{l}\text { Imam Malik } \\
\text { Islamic Centre }\end{array}$ \\
\hline $\begin{array}{l}\text { Tafseer from Government } \\
\text { House (Hausa) }\end{array}$ & & Sunday & $11: 00 \mathrm{pm}$ & One hour & Free \\
\hline $\begin{array}{l}\text { Tafseer Indimi Mosque } \\
\text { (Hausa) }\end{array}$ & $\begin{array}{l}\text { Dr Muhammad Alhaji } \\
\text { Abubakar }\end{array}$ & Monday & $11: 00 \mathrm{pm}$ & One hour & $\begin{array}{l}\text { Indimi Islamic } \\
\text { Trust }\end{array}$ \\
\hline $\begin{array}{l}\text { FOMWAN Da'awah (Hausa } \\
\text { or Kanuri) }\end{array}$ & $\begin{array}{l}\text { Alternating FOMWAN } \\
\text { members }\end{array}$ & Tuesday & 09:00am & $\begin{array}{c}30 \\
\text { Minutes }\end{array}$ & Free \\
\hline $\begin{array}{l}\text { Tafseer from Al-Ansar } \\
\text { Mosque (Hausa) }\end{array}$ & Dr Yahuza Abdullahi & Tuesday & $11: 00 \mathrm{am}$ & One hour & Al-Ansar Mosque \\
\hline $\begin{array}{l}\text { Tafseer from Hausari Layin } \\
\text { Sarkin Hausawa }\end{array}$ & Sheikh Kabiru Danyaya & Tuesday & $11: 00 \mathrm{pm}$ & One hour & Unknown \\
\hline Islam Today & Ustaz Adebayo & Wednesday & 09:00 am & 30 minutes & Free \\
\hline Nur Islambe (Hausa) & $\begin{array}{c}\text { Sheikh Muhammad } \\
\text { Mustapha }\end{array}$ & Wednesday & 11:00am & One hour & Unknown \\
\hline $\begin{array}{l}\text { Tafseer from Imam Malik } \\
\text { (Kanuri) }\end{array}$ & Sheikh Abubakar Kyari & Wednesday & 08:00 pm & One hour & $\begin{array}{l}\text { Imam Malik } \\
\text { Islamic Centre }\end{array}$ \\
\hline $\begin{array}{l}\text { Tafseer Daggash Mosque } \\
\text { (Hausa) }\end{array}$ & $\begin{array}{l}\text { Sheikh Muhammad } \\
\text { Mustapha }\end{array}$ & Wednesday & $11: 00 \mathrm{pm}$ & One hour & $\begin{array}{l}\text { Al-Amin Daggash } \\
\text { Islamic Centre }\end{array}$ \\
\hline Fiqh & $\begin{array}{l}\text { Alternating Sheikh } \\
\text { Yunus and Late Dr Ali } \\
\text { Mustapha }\end{array}$ & Thursday & 09:00 am & 30 minutes & Free \\
\hline Islamic Medicine (Hausa) & Mal Ja'afar & Thursday & 10:00 am & 30 minutes & Free \\
\hline Islamic Quiz (Hausa) & Alternating & Thursday & $04: 30 \mathrm{pm}$ & 30 minutes & Free \\
\hline $\begin{array}{l}\text { Tafseer from MOGCOLIS } \\
\text { (Hausa) }\end{array}$ & Sheikh Tijjani Umara & Thursday & $11: 00 \mathrm{pm}$ & One hour & MOGCOLIS \\
\hline Qur'anic recitation & Alternating & Friday & 08:00 am & $\begin{array}{l}\text { No specific } \\
\text { duration }\end{array}$ & Free \\
\hline
\end{tabular}




\begin{tabular}{|c|c|c|c|c|c|}
\hline Title of The Programme & Presenter & $\begin{array}{c}\text { Days of } \\
\text { Broadcast }\end{array}$ & Time & Duration & Sponsor \\
\hline $\begin{array}{l}\text { Al'ulamu rashidun } \\
\text { (Hausa or Kanuri, live) } \\
\text { programme }\end{array}$ & Alternating scholars & Friday & 10:00 am & One hour & Free \\
\hline $\begin{array}{l}\text { You and Islam } \\
\text { (Documentary) }\end{array}$ & Nil & Friday & $11: 00 \mathrm{am}$ & 30 minutes & Free \\
\hline Babban Guzuri & $\begin{array}{l}\text { Sheikh Muhammad } \\
\text { Mustapha }\end{array}$ & Friday & 08:00 pm & One hour & $\begin{array}{c}\text { Ahmed Babawo } \\
\text { Jaha }\end{array}$ \\
\hline $\begin{array}{l}\text { Tafseer from Shettima Ali } \\
\text { Monguno Mosque Mafoni }\end{array}$ & Goni Modu Goni Zarami & Friday & $11: 00 \mathrm{pm}$ & One hour & Unknown \\
\hline Hadith (Kanuri) & Goni Abba Umar & Saturday & 05:00 pm & 30 minutes & Free \\
\hline Tarbiya (Hausa) & $\begin{array}{l}\text { Dr Muhammad Alhaji } \\
\text { Abubakar }\end{array}$ & Saturday & 08:00 pm & One hour & Free \\
\hline $\begin{array}{l}\text { Tafseer from Taha } \\
\text { Qur'anic Memorisation }\end{array}$ & Imam Goni Ali Modu & Saturday & $11: 00 \mathrm{pm}$ & One hour & $\begin{array}{l}\text { Taha Qur'anic } \\
\text { Memorisation }\end{array}$ \\
\hline Centre & & & & & Centre \\
\hline
\end{tabular}

Source: BRTV, fieldwork 2019

Table 3 contains programmes broadcast during the 2019 Ramadan fasting period. The data further show that nearly six to seven hours of Islamic programmes were broadcast each day throughout the one-month Ramadan fasting season. That is to say, if the total number of hours the station broadcasts daily was 14 (from 07:00 am to 07:00 pm), then, on average, NTA Maiduguri allocated about 45 to $50 \%$ of its daily airtime to Islamic programmes during the Ramadan period; and, obviously, this is extremely more than the $10 \%$ of daily airtime stipulated in the NBC code. Traditionally, this is the normal practice in the broadcast outlet annually. This suggests that NTA Maiduguri 'technically' violated the NBC code. However, it is not known if this violation of the code had attracted any form of sanction against the station. Future research should investigate this issue.

Table 3: The inventory of religious programmes contained in the programme schedule of NTA Maiduguri during the Ramadan fasting season

\begin{tabular}{|c|c|c|c|c|c|}
\hline Title of Programme & Presenter & $\begin{array}{c}\text { Time of } \\
\text { Broadcast }\end{array}$ & Duration & Sponsor & Genre \\
\hline Tafseer from Ansar & Dr Yahuza Abdullahi & $8: 00-$ & One & Ansar Mosque & Recorded \\
\hline Mosque & & 08:55 pm & hour & & \\
\hline Tafseer from Imam & Sheikh Abubakar & 10:00- & One & Imam Malik & Recorded \\
\hline Malik Centre & Kyari & $10: 55 \mathrm{pm}$ & hour & Islamic Centre & \\
\hline Tafseer from Indimi & Dr Muhammad & 11:00- & One & Indimi Islamic & Recorded \\
\hline Mosque & Alhaji Abubakar & $12: 00 \mathrm{pm}$ & hour & Trust & \\
\hline *Tafseer from & Sheikh Ibrahim & 06:00- & One & Free & Recorded \\
\hline Government House & Mustapha Al-Malik & $06: 55 \mathrm{am}$ & hour & & \\
\hline$* *$ Tafseer from & Goni Abba Umar & 06:00- & One & Free & Recorded \\
\hline Maiduguri Central & & 06:55 am & hour & & \\
\hline \multicolumn{6}{|l|}{ Mosque } \\
\hline Tafseer from Al-Amin & Sheikh Muhammad & 10:00- & One & Al-Amin Daggash & Recorded \\
\hline Daggash Mosque & Mustapha & $10: 55 \mathrm{am}$ & hour & Islamic Foundation & \\
\hline Tafseer from Izala & Sheikh Muhammad & 11:00- & One & Izala Jos faction & Recorded \\
\hline Jos faction, Gwange & Musa Bako & $11: 55 \mathrm{am}$ & hour & & \\
\hline Mosque & & & & & \\
\hline
\end{tabular}


Ibrahim Uba Yusuf, Musa Usman, \& Adamkolo Mohammed Ibrahim, A comparative study of BRTV and NTA...

\begin{tabular}{|c|c|c|c|c|c|}
\hline Title of Programme & Presenter & $\begin{array}{c}\text { Time of } \\
\text { Broadcast }\end{array}$ & Duration & Sponsor & Genre \\
\hline ***Jawabi Kan Azumi & $\begin{array}{c}\text { Any prominent } \\
\text { scholar based in } \\
\text { Maiduguri }\end{array}$ & $\begin{array}{c}\text { 06:55- } \\
07: 00 \mathrm{pm}\end{array}$ & $\begin{array}{c}5 \\
\text { minutes }\end{array}$ & Free & Recorded \\
\hline $\begin{array}{l}* * * * \text { Bayan kla Ashem } \\
\text { mben }\end{array}$ & $\begin{array}{c}\text { Any prominent } \\
\text { scholar based in } \\
\text { Maiduguri }\end{array}$ & $\begin{array}{c}\text { 06:55- } \\
07: 00 \mathrm{pm}\end{array}$ & $\begin{array}{c}5 \\
\text { minutes }\end{array}$ & Free & Recorded \\
\hline
\end{tabular}

Note: Source: Fieldwork, NTA Maiduguri, 2019;

**** The programmes were broadcast interchangeably, with similar synopsis and content, but different broadcast languages.

Table 4 indicates the religious programmes broadcast on NTA Maiduguri after the month of Ramadan. Much less of religious programmes were broadcast during this period. Only four days (Wednesday, Thursday, Friday and Sunday) had any religious programme broadcast, with Sunday having two schedules, one for Islamic and the other for Christian religious programmes. According to this programme schedule, only a total of three hours of religious programmes were broadcast every week during the post-Ramadan period in the $2^{\text {nd }}$ quarter of 2019. Interestingly, it is only during post-Ramadan periods that Christian religious programmes have their way on air. Furthermore, every week throughout the non-Ramadan period only onehour airtime was allocated to Christian religious programmes while two hours were allocated to Islamic religious programmes. Overall, nearly 20\% of the total airtime of NTA Maiduguri was allocated to religious programmes during non-Ramadan times, a percentage that exceeds the NBC broadcasting code of $10 \%$ by nearly $100 \%$. Interestingly, however, it is only during non-Ramadan times that the station's adherence or compliance to the NBC code is within the ranges of $15 \%$ to $20 \%$, which is closer to the $10 \%$ stipulated by the Nigerian broadcast industry umpire, the NBC.

Table 4: The inventory of Islamic programmes contained in the programme schedule of NTA Maiduguri during the $2^{\text {nd }}$ Quarter of 2019

\begin{tabular}{|c|c|c|c|c|}
\hline Title of Programme & Presenter & $\begin{array}{c}\text { Time and Day of } \\
\text { Broadcast }\end{array}$ & Duration & Sponsor \\
\hline Nasiha in Hausa & $\begin{array}{l}\text { Any prominent scholar } \\
\text { based in Maiduguri }\end{array}$ & $\begin{array}{c}\text { 05:00 pm, every } \\
\text { Thursday }\end{array}$ & $\begin{array}{c}30 \\
\text { minutes }\end{array}$ & Free \\
\hline Hadith in Kanuri & $\begin{array}{l}\text { Any prominent scholar } \\
\text { based in Maiduguri }\end{array}$ & $\begin{array}{c}\text { 05:00 pm, every } \\
\text { Friday }\end{array}$ & $\begin{array}{l}30 \\
\text { minutes }\end{array}$ & Free \\
\hline Christian Half Hour & $\begin{array}{c}\text { Pastor and members of } \\
\text { choir }\end{array}$ & $\begin{array}{l}\text { 03:00 pm, every } \\
\text { Sunday }\end{array}$ & $\begin{array}{l}30 \\
\text { minutes }\end{array}$ & Free \\
\hline $\begin{array}{l}\text { No title. However, } \\
\text { the synopsis is clear. }\end{array}$ & Nil & $\begin{array}{c}\text { 12:00 pm every } \\
\text { Sunday }\end{array}$ & $\begin{array}{l}30 \\
\text { minutes }\end{array}$ & $\begin{array}{l}\text { Christ } \\
\text { Embassy }\end{array}$ \\
\hline Tafseer from Indimi & Late Sheikh Jaafar & 05:00 pm, every & One & Indimi \\
\hline Mosque & Mahmud Adam & Wednesdays & hour & $\begin{array}{l}\text { Islamic } \\
\text { Trust }\end{array}$ \\
\hline
\end{tabular}

Source: NTA Maiduguri fieldwork, 2019

$R Q_{3}$ : How frequent do BRTV and NTA Maiduguri broadcast religious programmes?

Based on the programme schedule obtained from the two stations, findings reveal that religious programmes have a higher percentage of airtime allocation. In BRTV for instance, out of 18 programmes broadcast in a day (for morning and evening transmissions), 10 programmes are religious (Imam, Personal communication 2019). In Ramadan, all programmes except for news, are suspended. Because they have been paid for, religious programmes don't fail, and repeat versions are avoided, except on rare occasion. Imam attributed this to the fact Borno 
is a Muslim state, as such they give priority attention to programmes with Islamic colouration. In NTA Maiduguri as noted by Gana (personal communication, 2019), there are only 4 religious programmes: 2 Islamic and 2 Christian.

$R Q$ 4: What are similarities in the mode of the broadcast of religious programmes in BRTV \& NTA Maiduguri?

Most of the religious programmes are duplicated in both stations. Some bear the same name, synopsis and style. Majority of the Islamic programmes in BRTV are recorded, except for Al'ulamu rashidun which is LIVE and free of charge. In NTA, all the religious programmes are recorded and broadcast free of charge except for a Christian program that has gotten sponsorship from Christ Embassy.

The two stations have allocated time for the broadcast of religious programmes at an odd time that is not prime time. The time is usually not characterized by heavy viewers.

$R Q$ 5: Are there ethical violations on religious programmes broadcast on BRTV and NTA Maiduguri?

During Ramadan, the two stations allocate more than $10 \%$ of the total airtime to religious programmes. In BRTV for instance, there is no balance in the broadcast of religious programmes. There is no single Christian programme for the Christian viewer. Given the fact that Borno is a secular state with a Muslim majority, however, there is a need for balance.

Imam (personal Communication, 2019) told these researchers that since 1992 there has not been any Christian programme on BRTV. Christian issues are only covered in the news. This is not farfetched from staff composition, viewers need and perhaps the absence of sponsors.

NBC had written several letters to BRTV to downplay religious programmes...

In NTA, there seems to be balanced. While Islamic religious programmes are broadcast in Hausa and Kanuri, because viewers and Muslims are predominantly Hausa and Kanuri speakers, Christian programmes are also in English. Each programme address viewers appeal. Gana (personal communication, 2019) notes that the religious programmes are locally produced, and each scholar invited as a guest or discussant in the programmes, comes with his student to serve as an anchor.

Religious broadcast in Nigeria Television Authority (NTA) Maiduguri and Borno Radio Television (BRTV) occupies an important place in programmes schedules. The two television stations place a high premium on their broadcast during Ramadan and beyond. The turnover generated from the broadcast of religious content in Ramadan is significantly higher than any other month. BRTV charges the sum of two hundred and fifty thousand Naira for the transmission of religious content for the period of Ramadan, while outside Ramadan, it charges one hundred and fifty thousand Naira Muhammad, (personal communication, 2019).

Mele (personal communication, 2019) NTA Maiduguri, on the other hand, charges the sum of five hundred thousand Naira per religious broadcast for the month of Ramadan (though, subjects to bargain), while outside the month of Ramadan, it charges three hundred and ninety thousand Naira for the quarter.

\section{CONCLUSION}

This paper concludes that religious programmes play a key role in managing and sustaining the operations of BRTV and NTA Maiduguri during Ramadan. Airtimes are sold to the highest bidder by the stations. The Ramadan period is a time for making brisk business. Concisely, the findings of this study suggest that in both BRTV and NTA Maiduguri: (1) the airtime allocated to (Islamic) religious programmes was far more than the $10 \%$ limit stipulated by the National Broadcasting Commission while BRTV Maiduguri allocated more airtime to religious programmes than did NTA Maiduguri; (2) Islamic religious programmes were allocated more airtime than programmes of other religions; and (3) presumably, because of its being owned by the Borno State Government, BRTV broadcast more Islamic religious 
programmes during Ramadan period than did NTA Maiduguri, which is owned by the Federal (national) Government. Therefore, this chapter recommends that: (1) the NBC should review its broadcasting code on religious programmes in such a way that more airtime is allocated for religious programmes during annual religious seasons such as Ramadan and Eid-el Kabir (for Muslims) and Ester and Christmas (for Christians); (2) rather than capitalising on the regulation of programme airtime, the NBC should promulgate a religious broadcast content code that will focus on the actual content of religious programmes (specifically texts, language and meaning) in such a way that the content does not contain malicious and inflammatory remarks capable of undermining the peace in the society.

\section{REFERENCES}

Adebiyi, R. A. \& Salaudeen, K. A. (2016). The changing face of political communication in Nigeria: A do-ordie media game. In D. Wilson (Ed.), Mass media and the electoral process in Nigeria (pp.209-220). Uyo: ACCE.

Adum, A. N. \& Ojiakor, O. E. \& Nnatu, S. (2019). Party politics, hate speech and the media: A developing society perspective. Journal of Humanities and Social Policy, 5(1), 45-54

Ahmad, G. \& Isa, K. H. (2017). Islamic groups and contestation for religious public space on radio stations in Kano Metropolis. In U. A. Pate \& L. Oso (Eds.), Multiculturalism, diversity and reporting conflict in Nigeria. Ibadan: Evans Brothers Limited.

Anifowose, B. O. (2013). Exploring radio as a means of disseminating development messages. Department of Communication and Language Art. University of Ibadan, Ibadan. Nigeria.

Bala, M. (200o). Pluralism and prior restraint on religious communication in Nigeria: Policy versus Praxis. In J. Thierstein \& Y. R. Kamalipour (Eds.), Religion, law, and Freedom: A Global Perspective (pp.
98-111). London: Praeger.

Creswell, J. W. \& Poth, C. N. (2017). Qualitative inquiry and research design: Choosing among five approaches. New Delhi: Sage Publications.

Damaris P. S. (2006). Then sings my soul': Gospel music as popular culture in the spiritual lives of Kenyan Pentecostal/ Charismatic Christians". Journal of Religious and Popular Culture, XIV. Retrieved from http://www.usask.ca/ relst/jrpc/art14-singsmysoul.html

Dominick, J.R. (2009). The dynamics of mass communication: Media in the digital age (1oth ed.). New York: McGraw-Hill.

Falola, T. \& Heaton, M. M. (2008). A history of Nigeria. Cambridge: Cambridge University Press.

Goodwin, C. (2009). Research in psychology: Methods and design. Hoboken, NJ.: John Wiley and Sons.

Hackett, R. I. J. (1998). Charismatic/ Pentecostal appropriation of media technologies in Nigeria and Ghana. Journal of Religion in Africa, 28(3), 258277. doi: 10.1163/157006698Xooo26

Harvey, S. (1999). Broadcasting regulation: On the side of the angels? Retrieved from h t t p : / / w w w. latrobe.edu.au / screeningthepast/firstrelease

Ibrahim, A. M. (2017). Factors affecting ICT usage for the development of small and medium-scale agro-based enterprises in Selangor, Malaysia, (Unpublished master's thesis), Universiti Putra Malaysia.

Ibrahim, A. M., Pate, U. A., \& Usman, A. M. (in press). Silencing the media and chaining the watchdog: Threats to journalists' safety during elections in Nigeria. In S. Jamal (Ed.), Combatting threats to media freedom and journalists' safety (ch. 12). Hershey: IGI Global.

Ibrahim, A. M., Yar'Adua, S. M. \& Maikaba, B. (2019). More media, less democratisation of public access and 
participation: A conceptual review of the influence of deregulation and commercialisation on public broadcasting in Nigeria. International Journal of Telecommunications and Information Technology, 3(1), 032-046.

Ihechu, I. P. (2019). Broadcasting and promotion of development in SubSaharan Africa. Journal of Development and Communication Studies, 6(1), 4860 .

Ihechu, I.P.\&Okugo,U.C.(2013). Broadcasting regulation and broadcasting in Nigeria: An overview of the approaches. Research on Humanities and Social Sciences, 3(2), 12-19. doi: 10.1207/ s15327728jmme1104_3

Jeffrey, C. L. (1996). An ethics code postmortem: The National Religious Broadcasters' EFICOM. Journal of Mass Media Ethics, 11(4), 223-35.

Johannes, H. (2008). Democratization and Islamic Law: The Sharia Conflict in Nigeria, Frankfurt: Campus Verlag.

Lindlof, T. R., \& Taylor, B. C. (2002). Qualitative communication research methods, Thousand Oaks, CA: Sage.

Malaolu, P. O. (2012). Media representation and democracy in Africa: 'Why there are no skyscrapers in Nigeria' - A critical analysis of UK news media's representation of Nigeria's democracy, 1997-2007. (Unpublished doctoral dissertation). University of Sterling, UK.

Marshall, C. \& Rossman, G. B. (2014). Designing qualitative research. London: Sage publications.

McBurney, D. \& White, T. (2009). Research methods (8th Ed.). Belmont, CA: Wadsworth, Centage Learning.

NBC (2009, September 3). Grant of radio and television network service licences. [Information Memorandum] Abuja: Retrieved from http://www.nbc.gov. org.php?

Nwanze, I. (2003). Broadcasting in Nigeria: Private broadcasting, prospects, challenges, legal aspects. Port Harcourt: Renaissance Communications Ltd.

Okunna, C. (2005 January). Re-inventing media content in Nigeria: Creating a balance between social responsibility and business concern. International Journal of Communication, 2, 88-96

Owuamalam, E (2006). Introduction to broadcasting. Owerri: Top class Agencies Ltd.

Tijani-Adenle, G. (2019). Women in Nigerian news media: Status, experiences and structures. (Unpublished doctoral thesis), De Montfort University, Leicester, the United Kingdom.

Ukah, A. (2011). Banishing miracles: politics and policies of religious broadcasting in Nigeria. Politics and Religion, 5(1), 39-6o.

Van Dijk, T. A. (1993). Principles of critical discourse analysis. Discourse and Society, 4(2), 249-283. doi: 10.1177/0957926593004002006 